Situs Jurnal : $\underline{\text { http://ejurnal.stiepancasetia.ac.id/index.php/jieb }}$

Jilid 4 Nomor 1 Maret 2018

Hal $014-028$

\title{
PENGARUH KEPEMIMPINAN KEPALA SEKOLAH DAN KOMPETENSI PROFESIONAL GURU DALAM MENINGKATKAN KINERJA GURU PADA SMPN 4 BANJARBARU
}

\begin{abstract}
Siti Fatimah*
The purpose of this research is to test and analyze the influence between principal leadership and teacher competence on teacher performance at SMPN 4 Banjarbaru simultaneously and partially. The method used is the Explanatory. The population of this study were teachers in SMPN 4 Banjarbaru totaling of 63 people. The sampling technique used is Porpusive with research sample is determined as many as 30 people used as sample research. Data were collected through questionnaires and documentation. Further analyzed by using regression. The result of the research shows that there is a significant influence simultaneously and partially between principal leadership and professional competence on teacher performance of SMPN 4 Banjarbaru, in which principal leadership has dominant influence to teacher performance.
\end{abstract}

Keywords: leadership, professional competence and teacher's performance

Tujuan penelitian ini adalah untuk menguji dan menganalisis pengaruh yang signifikan secara simultan maupun parsial antara kepemimpinan kepala sekolah dan kompetensi guru terhadap kinerja guru pada SMPN 4 Banjarbaru. Metode yang digunakan adalah Ekplanatori. Populasi penelitian ini adalah Guru di SMPN 4 Banjarbaru berjumlah 63 orang. Teknik pengambilan sampel yang digunakan adalah Porpusive yakni sampel penelitian ditentukan sebanyak 30 orang dijadikan sampel penelitian. Data dikumpulkan melalui angket dan dokumentasi. Selanjutnya dianalisa dengan menggunakan regresi. Hasil penelitian menunjukan bahwa terdapat pengaruh signifikan secara simultan maupun parsial antara kepemimpinan kepala sekolah dan kompetensi profesional terhadap kinerja guru SMPN 4 Banjarbaru, yang mana kepemimpinan kepala sekolah mempunyai pengaruh dominan terhadap kinerja guru.

Kata Kunci: kepemimpinan, kompetensi profesional, kinerja guru

\section{Latar Belakang}

Dunia pendidikan dewasa ini masih mengalami berbagai permasalahan dalam berbagai segi, di antaranya mutu pendidikan. Masalah rendahnya mutu pendidikan, menjadi topik hangat yang banyak dibicarakan oleh berbagai kalangan dunia pendidikan. Program pembangunan dibidang pendidikan belum dapat diwujudkan sepenuhnya di semua jenjang pendidikan dan jenis pendidikan. Yang menjadi penyebab diantaranya kemampuan dan disiplin tenaga pendidikan yang masih perlu ditingkatkan, kondisi lingkungan yang berbeda-beda, ruangan dan peralatan yang belum memenuhi persyaratan, serta dana yang terbatas dan kurang terarah penggunaannya.

Kenyataan ini mengharuskan guru untuk selalu meningkatkan kemampuannya terutama memberikan keteladanan, membangun kemauan, dan mengembangkan kreativitas peserta didik dalam proses pembelajaran. 
Perspektif kebijakan pendidikan nasional menunjukkan bahwa terdapat tujuh peran utama kepala sekolah yaitu sebagai: (1) educator (pendidik); (2) manajer; (3) administrator; (4) supervisor (penyelia); (5) leader (pemimpin); (6) pencipta iklim kerja; dan (7) wirausahawan. Penjelasan tersebut menunjukkan bahwa salah satu peran utama kepala sekolah adalah pemimpin yang menjalankan fungsi. Kepala sekolah sebagai pendidik harus memiliki kemampuan membimbing tenaga kependidikan, membimbing peserta didik, mengembangkan tenaga kependidikan, mengikuti perkembangan iptek dan memberi contoh mengajar (Kepmendikbud nomor 0296/U/1996 )

Uraian-uraian tersebut menunjukkan arti penting dari kepemimpinan kepala sekolah terhadap keberhasilan organisasi sekolah dalam mencapai visi, misi, maupun tujuan sekolah. Perhatian terhadap kepemimpinan ini cukup penting, mengingat kepemimpinan berkaitan dengan bagaimana mengkondisikan berbagai sumber daya sekolah yang bermacam-macam sehingga organisasi sekokah dapat berjalan sesuai dengan harapan dari organisasi tersebut. Keunggulan-keunggulan dalam rangka mendukung kebijakan otonomisasi pendidikan nasional akan lebih mudah tercapai melalui kepemimpinan yang efektif dalam membangun daya saing sekolah.

Peningkatan mutu pendidikan ditentukan oleh kesiapan sumber daya manusia yang terlibat dalam proses pendidikan. Guru merupakan salah satu faktor penentu tinggi rendahnya mutu hasil pendidikan. Guru mempunyai posisi strategis maka setiap usaha peningkatan mutu pendidikan perlu memberikan perhatian besar kepada peningkatan guru, baik dalam segi jumlah maupun mutunya. Kinerja guru memerlukan perhatian serius dari semua pihak. Tidak hanya pemerintah tetapi semua masyarakat. Tjiptono (2003: 27) menyatakan bahwa untuk mencapai kualitas atau mutu, maka ada beberapa dimensi yang harus dicapai, diantaranya kinerja, keistimewaan, kehandalan, dan lain-lain. Herawan, (2009: 229) menyatakan bahwa tenaga pendidik dan kependidikan dalam proses pendidikan memegang peranan penting terutama dalam upaya membentuk watak bangsa melalui pengembangan kepribadian.

Pendidikan di SMPN 4 Banjarbaru juga mengalami berbagai permasalahan. Secara umum, permasalahan pendidikan tersebut diantaranya adalah: 1) Nilai rata-rata masih rendah, sebagai contoh rata-rata nilai Ujian Akhir Nasional Jenjang SMP tahun 2016/2017. Rata-rata ini lebih rendah jika dibandingkan dengan rata-rata nasional rata-rata provinsi Kalimantan Selatan. Rendahnya kualitas pendidikan dilihat dari UAN untuk tingkat Seklah Menengah Pertama merupakan cerminan rendahnya kualitas sistem pendidikan Rendahnya kualitas dan kompetensi guru secara kognitif dalam membina siswa serta kompetensi pedagofik yakni kurangnya kemampuan mengembangkan pembelajaran, semakin membuat laju perkembangan pendidikan belum maksimal. Bila ditinjau dan diamati masih banyak guru yang belum memiliki profesionalitas yang baik untuk kemajuan pendidikan secara global. Di tengah kehidupannya dengan penghasilan pas-pasan guru dituntut untuk survive dan menghasilkan output yang memiliki hasil belajar dan prestasi yang baik. Berdasarkan Peraturan Pemerintah (PP) Nomor 18 Tahun 2007 tentang Guru, dinyatakan bahwasannya salah satu kompetensi yang harus dimiliki oleh guru adalah kompetensi professional. Merupakan kemampuan seorang guru dalam penguasaan materi pelajaran secara luas dan mendalam yang meliputi penguasaan materi keilmuan, penguasaan kurikulum dan silabus sekolah, metode khusus pembelajaran bidang studi serta pengembangan wawasan etika dan pengembangan profesi..

Kinerja guru merupakan salah satu kebutuhan manusia yang harus terpenuhi dan merupakan cita-cita individu manusia yang pada hakikatnya selalu ingin meraih rasa senang dan kepuasan. Kinerja guru merupakan sifat individual seseorang yang berkorelasi dengan emosional. Yulk (2001: 464) kinerja guru sebagai sikap seseorang terhadap hasil kerja yang 
dicapainya, yang merupakan pengalaman yang menyenangkan dan merupakan harapan masa depan.

Keberhasilan kepemimpinan Kepala Sekolah sangat dipengaruhi oleh kepribadian yang kuat, memahami tujuan pendidikan dengan baik, memiliki pengetahuan yang luas, menguasai keterampilan teknis dan keluwesan berinteraksi serta memahami konsep manajerial. Dengan demikian, Kepala Sekolah harus dapat menempatkan dirinya, sesuai dengan tugas dan perannya di berbagai tindakan, agar segala kebijakan tidak disalahgunakan.

Menurut data Dinas Pendidikan, SMPN 4 Banjarbaru untuk tahun 2016/2017, memiliki 63 guru terlihat telah memenuhi standar dari segi jumlah dan beban kerja, namun dilihat dilihat adanya keanekaragaman dalam memberikan pengajaran sesuai kemampuannya, baik dilihat dari segi penampilan maupun dari segi pengelolaan yang telah membantu kegiatan sekolah masih menunjukan kepuasan, termasuk untuk loyalitas dan etos kerja yang memerlukan pembenahan. Hal ini terikat dengan adanya peran kepemimpinan kepala sekolah untuk membenahi hal tersebut.

Berdasarkan pada latar belakang yang telah dikemukakan sebelumnya, maka dapat disusun rumusan masalah sebagai berikut:

1. Apakah terdapat pengaruh yang signifikan secara simultan antara kepemimpinan kepala sekolah dan kompetensi guru terhadap kinerja guru pada SMPN 4 Banjarbaru ?

2. Apakah terdapat pengaruh yang signifikan secara parsial antara kepemimpinan kepala sekolah dan kompetensi guru terhadap kinerja guru pada SMPN 4 Banjarbaru?

3. Manakah antara kepemimpinan kepala sekolah dan kompetensi profesional guru yang memiliki pengaruh secara dominan terhadap kinerja guru SMPN 4 Banjarbaru ?

\section{Kajian Literatur}

Menurut Daryanto (1996: 166) kepemimpinan adalah keseluruhan aktivitas dalam rangka mempengaruhi orang-orang agar mau bekerja sama untuk mencapai tujuan yang memang diinginkan bersama. Kepemimpinan adalah bagian penting dari manajemen yang merupakan kemampuan yang dipunyai seseorang untuk mempengaruhi orang lain agar bekerja untuk mencapai tujuan dan sasaran (Handoko, 2003: 294).

Yukl (2001:3) menyatakan Kepemimpinan didefinisikan secara luas sebagai proses mempengaruhi interprestasi mengenai peristiwa-peristiwa bagi para pengikut, pilihan dari sasaran bagi kelompok tau organisasi, pengorganisasian dari aktivitas-aktivitas kerja untuk mencapai sasaran tersebut,. Leardership atau kepemimpinan merupakan bagian dari karakteristik individu. Pemimpin adalah individu yang dapat membangun suatu visi dan pera.saan bersama dalam suatu organisasi atau orang 7 -orang yang dipimpinnya.

Kepemimpinan adalah proses untuk mempengaruhi kegiatan kelompok yang terorganisasikan dalam usaha menentukan tujuan dan mencapainya.sedangkan dalam rumusan ini kepemimpinan diartikan sebagai kemampuan seseorang untuk mempengaruhi pihak lain untuk berbuat sesuai dengan kehendak orang itu.

Definisi mengenai kepemimpinan tersebut di atas mencerminkan bahwa kepemimpinan menyangkut sebuah proses pengaruh social yang dalam hal ini pengaruh yang sengaja dijalankan oleh seseorang terhadap orang lain untuk menstuktur aktivitas-aktivitas serta korelasi-korelasi dalam sebuah organisasi dan kelompok. Definisi-definisi tersebut berbeda di dalam berbagai aspek terutama siapa yang menggunakan pengaruh dan sarana yang ingin diperoleh dari pengaruh tersebut. Salah satu pandangan menyatakan bahwa semua kelompok mempunyai spesialis peran yang di dalamnya termasuk peran khusus kepemimpinan. Termasuk di dalam peran tersebut adalah beberapa tanggung jawab dan fungsi yang tidak dapat dibagibagi tanpa merugikan aktivitas kelompok tersebut. 
Dalam korelasinya dengan misi pendidikan, kepemimpinan dapat diartikan sebagai usaha kepala sekolah dalam memimpin, mempengaruhi, memberikan bimbingan kepada para personil pendidikan sebagai bawahan agar tujuan pendidikan dan pengajaran dapat tercapai melalaui serangkaian kegiatan yang telah direncanakan (Anwar, 2003: 70).

Agar kepemimpinan kepala sekolah efektif, beberapa sifat dan gaya kepemimpinan seorang pemimpin (kepala sekolah) dalam rnenggalang korelasi baik dengan orang-orang yang dipimpin yaitu (Atmodiwirio dan Totosiswanto, 2001: 73).

Kepala sekolah sebagai pemimpin pendidikan mempunyai tugas memadukan unsur-unsur sekolah dengan situasi lingkungan budayanya, yang merupakan kondisi bagi yang terciptanya sekolah yang afektif. Pemimpin dengan gaya demokratis lebih banyak mendelegasikan pekerjaan kepada bawahan dan ada kecenderungan untuk membantu bawahan dalam rangka memenuhi kebutuhannya. Ciri-ciri yang menonjol dalam kepemimpinana demokratis, yaitu: (1) ramah tamah, (2) mau berkonsultasi dengan bawahan, memikirkan kesejahteraan bawahan, (3) memperlakukan bawahan secara manusia, (4) selalu berupaya menciptakan suasana kerja yang menyenangkan, (5) lebih banyak memberikan motivasi, (6) membantu bawahan dalam menyelesaikan masalah pribadi mereka (Sutarto, 2001: 41).

Kepemimpinan dengan gaya kepemimpinan bebas, serba boleh merasa bahwa terciptanya tujuan dipikul oleh orang perorangan. Ciri-cirinya antara lain : (1) melimpahkan wewenang sepenuhnya kepada bawahan, (2) keputusan dan kebijaksanaan lebih banyak dibuat oleh bawahan, (3) pemimpin hanya berkomunikasi apabila diperlukan bawahan, (4) Prakarsa selalu datang dari bawahan, (5) hampir tidak ada pengarahan dari pimpinan (Sutarto, 2001: 42).

Peran kepala sekolah diaplikasikan dalam perilaku kepemimpinan kepala sekolah yang dapat diukur melalui:

1. keterbukaan, keterbukaan kepala sekolah dalam gaya kepemimpinan dilihat dari merumuskan kebijakan melalui musyawarah, mendelegasikan tugas dengan jelas dan pelaksanaan tata tertib organisasi dengan indokator adalah:

a. kepala sekolah merumuskan kebijakan secara demokratis, musyawarah dengan bawahan,

b. kepala sekolah mendelegasikan tugas dengan jelas terhadap Kepala Sekolah sehingga Kepala Sekolah dapat melaksanakan tugas dengan baik,

c. kepala sekolah menetapkan / menentukan tata tertib organisasi dan disepakati oleh Kepala Sekolah atau sekolah.

2. Perhatian terhadap bawahan, perhatian terhadap bawahan diindikasikan dari membentuk pekerjaan agar dapat dilaksanakan, meningkatkan moral dan semangat staf, memberikan ganjaran atas usaha perorangan, memberikan dorongan dan penghargaan, membantu staf mengatasi masalahnya dan keramahan dalam melakukan pendekatan dengan indikator adalah:

a. Kepala sekolah membantu pekerjaan Kepala Sekolah,

b. Kepala sekolah meningkatkan etika sosial dan semangat terhadap staf,

c. Kepala sekolah memberikan gambaran atas usaha perorangan,

d. Kepala sekolah memberi motifasi/dorongan, semangat dan penghargaan terhadap Kepala Sekolah atas keberhasilan Kepala Sekolah dalam tugasnya,

e. Kepala sekolah membimbing, membantu Kepala Sekolah yang mengalami kesulitan mengajar maupun masalah pribadi lainnya,

f. Kepala sekolah penuh keramahan dalam menyelesaikan masalah dan bersikap pengasih terhadap bawahan.

3. Interaksi, interaksi terefleksi digambarkan sebagai sikap kepemimpinan sebagai usaha untuk membina korelasi yang harmonis dengan indikator: 
a. Kepala sekolah membina korelasi yang harmonis sesama warga sekolah,

b. Kepala sekolah dapat menyesuaikan diri dengan situasi organisasi yang telah dibentuk sekolah.

4. Pengambil keputusan, kepala sekolah mengembangkan nilai-nilai kehidupan sekolah yang demokratis serta kepala sekolah perduli terhadap lingkungan sekolah dengan indikator adalah:

a. Kepala sekolah mengembangkan nilai-nilai kehidupan sekolah yang demokratis terhadap warga sekolah,

b. Kepala sekolah peduli terhadap kekurangan sekolah dan berusaha menyediakan, melengkapinya (Wahjosumidjo, 2003:29).

Charles (Mulyasa, 2007 : 25) mengemukakan bahwa : kompetensi merupakan perilaku yang rasional untuk mencapai tujuan yang dipersyaratkan sesuai dengan kondisi yang diharapkan). Sedangkan dalam Undang-undang Republik Indonesia Nomor 14 Tahun 2005 tentang Guru dan Dosen dijelaskan bahwa : "Kompetensi adalah seperangkat pengetahuan, keterampilan, dan perilaku yang dimiliki, dihayati, dan dikuasai oleh guru atau dosen dalam melaksanakan keprofesionalan."

Kompetensi merupakan komponen utama dari standar profesi di samping kode etik sebagai regulasi perilaku profesi yang ditetapkan dalam prosedur dan sistem pengawasan tertentu. Kompetensi diartikan dan dimaknai sebagai perangkat perilaku efektif yang terkait dengan ekspolarasi dan investasi, menganalisis dan memikirkan, dan memberikan perhatian, dan mempersepsi yang mengarahkan seseorang menemukan cara-cara untuk mencapai tujuan tertentu secara efektif dan efisien Kompetensi bukanlah suatu titik tertentu secara efektif dan efisien. Kompetensi bukanlah suatu titik akhir dari suatu upaya melainkan suatu proses yang berkembang dan belajar sepanjang hayat.

Istilah kompetensi guru mempunyai banyak makna, Broke and Stone (Mulyasa, 2007 : 25) mengemukakan bahwa kompetensi guru sebagai komptensi guru merupakan gambaran kualitatif tentang hakikat perilaku guru yang penuh arti.

Menurut Mulyasa kompetensi guru merupakan perpaduan antara kemampuan personal, keilmuan, sosial, spiritual yang secara kaffah membentuk kompetensi standar profesi guru yang mencakup penguasaan materi, pemahaman terhadap peserta didik, pembelajaran yang mendidik, pengembangan pribadi dan profesionalisme.

Jadi kompetensi profesional guru dapat diartikan sebagai kemampuan dan kewenangan guru dalam menjalankan profesi keguruannya. Guru yang kompeten dan profesional adalah guru piawai dalam melaksanakan profesinya. Berdasarkan uraian di atas kompetensi guru dapat didefinisikan sebagai penguasaan terhadap pengetahuan, keterampilan, nilai dan sikap yang direfleksikan dalam kebiasaan berpikir dan bertindak dalam menjalankan profesi sebagai guru.

Depdiknas (2004:7) merumuskan definisi kompetensi sebagai pengetahuan, keterampilan, dan nilai-nilai dasar yang direfleksikan dalam kebiasaan berfikir dan bertindak. Menurut Syah (2000:230), "kompetensi”" adalah kemampuan, kecakapan, keadaan berwenang, atau memenuhi syarat menurut ketentuan hukum. Selanjutnya masih menurut Syah, dikemukakan bahwa kompetensi guru adalah kemampuan seorang guru dalam melaksanakan kewajiban-kewajibannya secara bertanggung jawab dan layak.

Kompetensi profesional guru dapat diartikan sebagai kemampuan dan kewenangan guru dalam menjalankan profesi keguruannya. Guru yang kompeten dan profesional adalah guru piawi dalam melaksanakan profesinya.Berdasarkan uraian di atas kompetensi guru dapat didefinisikan sebagai penguasaan terhadap pengetahuan, keterampilan, nilai dan sikap yang direfleksikan dalam kebiasaan berpikir dan bertindak dalam menjalankan profesi sebagai guru. 
Kinerja menjadi hal yang penting dan mendapat perhatian serius dari berbagai kalangan terutama untuk perusahaan yang bergerak di bidang jasa. Tidak terkecuali dengan dunia pendidikan. Pengukuran kinerja dalam dunia pendidikan sebenarnya bukan hanya ditujukan untuk profesi guru saja tetapi elemen pendukung lainnya seperti bagian staff akademik, bagian administrasi, bagian kebersihan, dan bagian lainnya. Karena semua saling mendukung tercapainya mutu pendidikan.

Berkaitan dengan kinerja guru, dapat dikategorikan dalam kinerja individu. Hal ini disebabkan karena setiap guru mempunyi kualifikasi dan motivasi yang berbeda - beda dalam menjalankan profesinya. Untuk kinerja individu, Mathis, dan Jackson (Narimawati, 2005 ) menyatakan "In most organization the performance of individual employees is a major determinant of organization success". Sedangkan Albanes dan Soelaiman Sukmana (Narimawati, 2005) merinci factor kinerja individu dalam tiga factor; (a) abilities and skill, (b) role perception, dan (c) effort or motivation. Senada dengan Albanes dan Soelaiman Sukmana, teori Mathis, dan Jackson (Narimawati, 2005) juga mengemukakan faktor yang mempengaruhi kinerja individu dalam tiga faktor, yaitu; (a) individual ability to do the work, (b) effort level expended, and (c) orgazational support.

Untuk mengetahui tinggi rendahnya kinerja guru dalam melakukan pekerjaannya maka diperlukan adanya ssstem penilaian terhadap kinerja guru maka cara yang digunakan untuk mengukur pekerjaan yang dilakukan sesuai dengan target yang telah ditetapkan. Sebagai tenaga professional, guru yang bekerja dan menjalankan tugasnya, profesi juga perlakukan dilakukan penilaian dalam menjalankan pekerjaannya sebagai pendidik. Pentingnya penilaian kinerja guru juga dikemukakan oleh Lewis (Narimawati, 2005) "Bahwa penilaian terhadap kinerja guru penting/ perlu dilakukan, mengingat guru dalam posisi penting dalam mempengaruhi pelaksanaan pendidikan mahasiswanya maka tidak mengherankan apabila pemerintah, orang tua mahasiswa, serta yang lain memeprhatikan mutu pendidikan melalui kemampuan seorang guru".

Gaffar (Narimawati, 2005) membagi kinerja guru menjadi tiga bidang besar, yaitu; (a) content knowledge, (b) behavior skill, dan (c) human relation skill. Sedangkan Sanusi dan Natawidjaja (Narimawati, 2005) membagi kinerja guru secara konseptual mencakup aspek kemampuan professional, kemampuan sosial, dan kemampuan pribadi. (1) Kemampuan professional meliputi ; penguasaan materi pelajaran yang terdiri atas penguasaan bahan yang harus diajarkan dan konsep - konsep dasar keilmuan dari bahan yang diajarkan, penguasaan dan penghayatan atas landasan/ wawasan kependidikan dan keguruan, penguasaan proses proses pendidikan, keguruan, dan pembelajaran siswa. (2) Kemampuan sosial mencakup; kemampuan untuk menyesuaikan diri kepada tujuan dan lingkungan sekitar pada waktu membawakan tugasnya sebagai guru. (3) Kemampuan pribadi mencakup: penampilan dan sikap yag positif terhadap keseluruhan situasi sebagai guru dan terhadap keseluruhan situasi pendidikan beserta unsure - unsurnya, pemahaman, penghayatan, dan penampilan norma norma yang seyogyanya dianut oleh seorang guru serta penampilan uapaya untuk menjadikan cirinya sebagai panutan dan teladan siswanya.

Selanjutnya disimpulkan dengan variabel dan indikator serta item dalam penelitian ini sebagai berikut:

1. Kualitas kerja dukur dari membuat persiapan mengajar yang baik penguasaan materi pengajaran dan hasil dari laporan pekerjaan.

2. Kuantitas kerja dukur dari banyaknya pekerjaan yang diselesaikan sesuai target dan kemampuan mengidentifikasi masalah-masalah yang berkaitan dengan pembelajaran

3. Kreativitas diukur dari mendorong siswa, mengadakah variasi dalam pembelajaran, menemukan cara-cara baru dalam menyelesaikan pekerjaan, kemampuan memanfaatkan peluang, mengambil keputusan dan memanfaatkan bahan pengajaran. 
4. Tanggung jawab diukur dari penyelesaian pekerjaan, mendahulukan tugas seklah, keuletan dalam menghadapi kesulitan pekerjaan, dan kewenangan yang diberikan sesuai prosedur

5. Kerjasama diukur dari hubungan kerjasama dengan sesama guru, hubungan kerjasama dengan siswa dan hubungan kerja dengan kepala sekolah.

6. Keselamatan kerja diukur dengan usaha untuk mencegah terjadinya kecelakaan kerja dan melaksanakan tugas dengan menerapkan aspek-aspek keselamatan kerja.

7. Loyalitas kerja diukur dari sumbangan pemikiran dalam usaha ikut memajukan sekolah, loyalitas terhadap lembaga dan kepala sekolah.

Beberapa penelitian terdahulu yang mendasari penelitian ini meliputi:

1. Muliani (2015). Hubungan Antara Fungsi Kepemimpinan dan Motivasi Kerja Guru Dengan Kedisiplinan Kerja Guru SMPN Di Kabupaten Banjarnegara . Hasil penelitian menunjukan kepemimpinan dan motivasi kerja guru memiliki hubungan yang signifikan dengan kedisiplinan kerja Guru SMPN Di Kabupaten Banjarnegara.

2. Yana Yulianita (2015). Hubungan Kepemimpinan Kepala Sekolah dan Kompetensi Profesional Guru dengan Kinerja Guru Bahasa Indonesia di SMP Negeri Se- Kabupaten Tanah Bumbu. Hasil penelitian menunjukan: (1) terdapat hubungan kepemimpinan kepala sekolah dengan kinerja guru SMP Negeri se- Kabupaten Tanah Bumbu, (2) Terdapat hubungan kompetensi profesional guru dengan kinerja guru SMP Negeri se- Kabupaten Tanah Bumbu, (3) terdapat hubungan kepemimpinan kepala sekolah dan kompetensi profesional guru dengan kinerja guru SMP Negeri se-Kabupaten Tanah Bumbu.

Berlandaskan pada serangkaian teori yang telah dikemukakan, serta ditunjang juga oleh penelitian terdahulu yang relevan, maka dapat disusun kerangka konseptual dan hipotesis dari penelitian ini, seperti ditunjukkan pada Gambar 1.

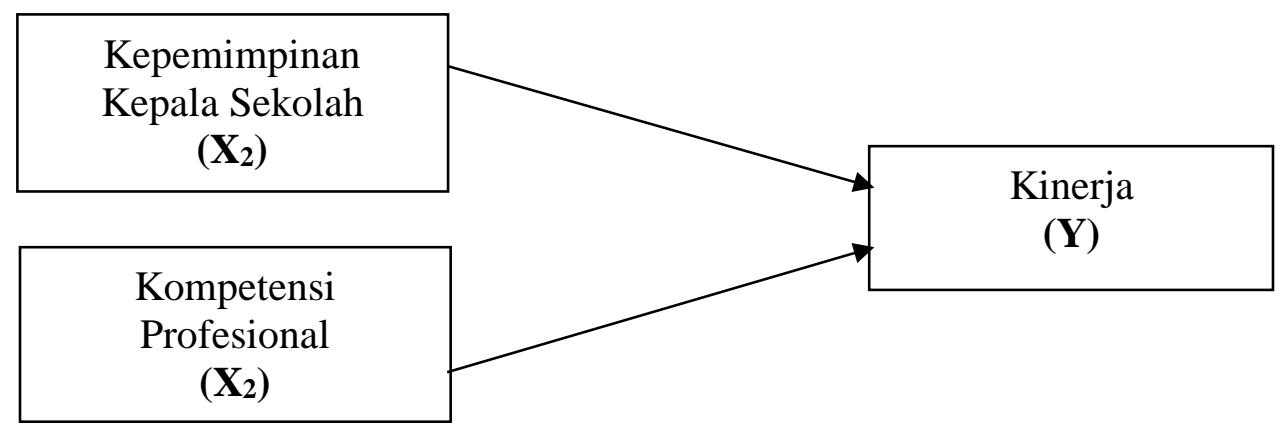

\section{Gambar 1. Model Kerangka Konseptual Penelitian}

Dari gambar 1 variabel X1, dan X2 digolongkan variabel indenpenden sedang variabel $\mathrm{Y}$ digolongkan variabel dependen. Penelitian ini berusaha menemukan korelasi kepemimpinan kepala sekolah terhadap kinerja guru, dan juga akan dilihat korelasi dari hasil kompetensi profesional guru terhadap kinerja guru. Seberapa besar pengaruh kompetensi profesional guru setelah dimurnikan dari pengaruh kepemimpinan semuanya akan dianalisis. Oleh karena itu, Hipotesis yang diajukan dalam penelitian ini adalah:

1. Terdapat pengaruh yang signifikan secara simultan antara kepemimpinan kepala sekolah dan kompetensi profesional guru terhadap kinerja guru pada SMPN 4 Banjarbaru.

2. Terdapat pengaruh yang signifikan secara parsial antara kepemimpinan kepala sekolah dan kompetensi profesional guru terhadap kinerja guru pada SMPN 4 Banjarbaru.

3. Terdapat pengaruh dominan antara kepemimpinan kepala sekolah dan kompetensi profesional guru terhadap kinerja guru pada SMPN 4 Banjarbaru. 


\section{Metode Penelitian}

Ditinjau dari permasalahan yang ada dalam penelitian maka penelitian termasuk penelitian kuantitatif. Metode ini digunakan untuk menggambarkan pengaruh yang terdapat diantara dua variabel atau lebih. Metode Ekplanatori dalam pene!itian ini digunakan untuk mengetahui kepemimpinan kepala sekolah dan kompetensi guru terhadap kinerja guru pada SMPN 4 Banjarbaru.

Populasi penelitian ini adalah seluruh guru SMPN 4 Banjarbaru, dengan jumlah 63 orang. Sampel penelitian adalah sebagian dari jumlah karakteristik yang dimiliki oleh populasi tersebut (Sugiyono, 2006:56). Sampel penelitian ini diambil secara propusive yaitu ditentukan hanya sebanyak 30 orang. yang berstatus Guru PNS.

meliputi:

Definisi Operasional dari masing-masing Variabel Penelitian pada penelitian ini

1. Kepemimpinan kepala sekolah.

Kemampuan kepala sekolah sebagai leardership memimpin / menggerak, membuat keputusan terhadap Kepala Sekolah dan melaksanakan tugas sebagai supervisor. Kemampuan kepala sekolah melakukan bimbingan, penilaian terhadap kerja sebagai motivator, memberikan semangat, dorongan, penghargaan terhadap pelaksaan pekerjaan Kepala Sekolah, kepala sekolah sebagai inisiator, kemampuan kepala sekolah melakukan kebijakan-kebijakan, perubahan terhadap kepentingan sekolah.

2. Kompetensi profesional guru

Surya (2003:138) mengemukakan kompetensi profesional adalah berbagai kemampuan yang diperlukan agar dapat mewujudkan dirinya sebagai guru profesional. Kompetensi profesional meliputi kepakaran atau keahlian dalam bidangnya yaitu penguasaan bahan yang harus diajarkannya beserta metodenya, rasa tanggung jawab akan tugasnya dan rasa kebersamaan dengan sejawat guru lainnya.

\section{Kinerja Guru}

Kinerja seorang pegawai pada dasarnya adalah hasil kerja seorang pegawai dalam periode tertentu dibandingkan dengan berbagai kemungkinan, misalnya: Bandar, target atau sasaran atau kinerja yang telah ditentukan terlebih dahulu dan telah disepakati bersama.

\section{Hasil Penelitian Dan Pembahasan}

Pelaksanaan penelitian yang dilakukan sesuai dengan permasalahan yang muncul kepermukaan dapat diketahui melalui langkah-langkah ilmiah sehingga kesahihan data dapat dipertanggungjawabkan.

1. Validitas dan Reliabitas Instrumen Penelitian

Dalam penelitian ini uji validitas dan reliabilitas dilakukan pada seluruh variabel yaitu kepemimpinan kepala sekolah dan kompetensi profesional serta Kinerja guru pada guru SMP Negeri 4 Banjarbaru. Dalam ini akan diuji cobakan secara langsung kepada seluruh sampel sebanyak 10 orang responden sesuai target penelitian maupun peran guru subyek yang diteliti.

a. Validitas Instrumen

Alat ukur kepemimpinan kepala sekolah dan kompetensi profesional serta Kinerja guru pada guru SMP Negeri 4 Banjarbaru akan dihitung validitasnya dengan analisis item, yaitu mengkorelasikan skor yang diperoleh setiap butir dengan skor total yang merupakan jumlah tiap skor butir dengan teknik korelasi product moment dengan taraf 
signifikansi 5\%. Perhitungan menggunakan program SPSS for Windows versi 18 . Uji validitas instrumen pada penelitian ini akan dilakukan terhadap 10 orang responden sesuai target penelitian dengan subyek yang diteliti.

Berdasarkan hasil uji validitas yang diterapkan pada 10 orang pada guru SMP Negeri 4 Banjarbaru sebagai survey pendahuluan atau uji coba yang penulis lakukan pada tanggal 20 S.D 25 oktober 2017, diketahui bahwa angket kepemimpinan kepala sekolah kompetensi profesional pada SMP Negeri 4 Banjarbaru yang berjumlah 10 item pernyataan diketahui sebanyak 10 item pernyataan valid dan berarti tidak terdapat pertanyaan yang tidak valid/gugur.

Sedangkan angket untuk kinerja guru SMP Negeri 4 Banjarbaru dalam penanganan masalah yang menyangkut guru yang berjumlah 10 item pernyataan diketahui sebanyak 10 item yang valid yang berarti juga tidak terdapat pertanyaan yang tidak valid/gugur. Uji validitas yang dilakukan dengan menggunakan teknik korelasi product moment kemudian membandingkan $r$ hasil dari tiap item pernyataan dengan $r$ Tabel sebesar 0,3169 (10 orang respoden) dengan asumsi jika $r_{\text {hasil }}$ lebih besar dari $r$ Tabel maka item tersebut adalah valid dan jika $r$ hasinya lebih kecil dari $r$ Tabel maka item pernyataan tersebut tidak valid.

b. Reliabilitas Instrumen

Setelah diketahui jumlah item yang valid selanjutnya dilakukan uji reliabilitas instrumen yang berorientasi pada satu pengertian bahwa kuesioner yang digunakan dalam penelitian ini dapat dipercaya untuk digunakan sebagai alat pengumpul data, uji reliabilitas sendiri menggunakan koefisien Cronbach Alpha dengan alat bantu SPSS versi 18 for Windows. Suatu angket dikatakan reliabel jika nilai $\mathrm{r}$ alpha yang dihasilkan adalah positif dan lebih besar dari $\mathrm{r}$.

Tabel 1. Hasil Uji Reliabilitas

\begin{tabular}{llc}
\hline No & \multicolumn{1}{c}{ Variabel } & Koefisien Cronbach's Alpha \\
\hline 1 & Kepemimpinan kepala sekolah & .751 \\
\hline 2 & Kompetensi profesional & .788 \\
\hline 3 & Kinerja guru & .778 \\
\hline
\end{tabular}

Variabel kepemimpinan kepala sekolah mempunyai $\mathrm{r}$ alpha sebesar 0.751dan kompetensi profesional mempunyai $\mathrm{r}$ alpha sebesar 0.788. Sedangkan untuk Kinerja guru mempunyai $\mathrm{r}$ alpha sebesar 0.778. Dari keempat nilai $\mathrm{r}$ alpha yang dihasilkan bernilai positif dan lebih besar dari $r$ Tabel ( $\mathrm{r}$ Tabel=0,3169) yang berarti keseluruhan instrumen penelitian ini handal dan dapat digunakan sebagai alat ukur dalam penelitian ini. Berdasarkan hasil uji validitas dan reliabilitas instrumen yang dilaksanakan semua item yang tidak valid/gugur tidak akan digunakan sebagai alat ukur pada saat penelitian berlangsung.

\section{Uji Asumsi Klasik}

Uji persyaratan klasik yang dilakukan sebelum data dimasukkan sebagai input dalam analisis regresi berganda sebagai berikut:

a. Uji Multikolinieritas

Pada penelitian ini hasil pengujian nilai VIF semuanya di bawah dari 0,5 sehingga dapat dibuat kesimpulan bahwa data dari tiga variabel yang diteliti tidak ada masalah multikolinieritas. 
Tabel 2. Multikolinieritas

\begin{tabular}{ccc}
\hline Variabel Bebas & VIF & Keterangan \\
\hline $\mathrm{X}_{1}$ & 1.189 & Tidak terjadi Multikolinieritas \\
\hline $\mathrm{X}_{2}$ & 1.221 & Tidak terjadi Multikolinieritas \\
\hline $\mathrm{X}_{3}$ & 1.255 & Tidak terjadi Multikolinieritas \\
\hline
\end{tabular}

\section{b. Uji Autokorelasi}

Uji ini dilakukan untuk mengetahui apakah dalam persamaan regresi mengandung korelasi serial atau tidak diantara variabel pengganggu. Menurut Nugroho ( 2013 : 62) Jika nilai Durbin watson hitung mendekati atau di sekitar angka 2, maka model tersebut terbebas dari asumsi klasik autokorelasi, karena angka pada uji Durbin Watson terletak di daerah No Autocorrelation. Dalam penelitian ini, hasil dari uji Durbin-Watson adalah sebesar 1.267.

c. Uji Normalitas

Pada penelitian ini, grafik uji normalitas (lampiran 3) terlihat titik-titik menyebar disekitar garis diagonal dan searah dengan garis tersebut, sehingga model regresi layak dipakai untuk prediksi variabel dependen berdasarkan masukan dari variabel independennya.

d. Uji Heterokedastisitas

Pada penelitian ini tidak terjadi gejala heterokedastisitas karena pada grafik scatterplott titik menyebar di atas dan di bawah angka 0 pada sumbu Y. ( Terlampir). Peneliti menyadari bahwa keterbatasan pengetahuan maupun bahan-bahan yang dijadikan sebagai pedoman penelitian belumlah mencukupi dengan sempurna. Namun demikian pada angket yang disebarkan dapat diharapkan memberi informasi dan data-data yang diperlukan.

Berdasarkan hasil rekapitulasi sesuai data penelitian maka diuraikan masing-masing pengaruh secara simultan, parsial serta dominan berikut.

1. Pengaruh Secara Parsial

Hasil pengujian secara parsial disajikan pada tabel 3 berikut.

\section{Tabel 3. Hasil Pengujian Secara Parsial}

\begin{tabular}{|c|c|c|c|c|c|}
\hline \multicolumn{6}{|c|}{ Coefficients $^{\mathrm{a}}$} \\
\hline \multirow[t]{2}{*}{ Model } & \multicolumn{2}{|c|}{$\begin{array}{l}\text { Unstandandarized } \\
\text { Coefficients }\end{array}$} & \multirow{2}{*}{$\begin{array}{c}\text { standandarized } \\
\text { Coefficients } \\
\text { Beta }\end{array}$} & \multirow[t]{2}{*}{$\mathrm{t}$} & \multirow[t]{2}{*}{ sig } \\
\hline & $\mathrm{B}$ & Std.error & & & \\
\hline 1. Constant) & 2.284 & .306 & & 7.415 & .000 \\
\hline Kepemimpinan Kepsek & .222 & .054 & .551 & 4.104 & .000 \\
\hline Kompetensi Profesional & .157 & .050 & .424 & 3.162 & .004 \\
\hline
\end{tabular}

a. Pengaruh Kepemimpinan Kepala Sekolah Terhadap Kinerja Guru

Berdasarkan Tabel 3 dapat dijelaskan bahwa dari variabel kepemimpinan kepala sekolah (X1) yang mempunyai nila t-hitung $>$ nilai t-Tabel $=4.104>2.000$ berarti bahwa variabel tersebut pada taraf nyata $(5 \%)$ mempunyai pengaruh yang bermakna terhadap kinerja guru pada SMP Negeri 4 Banjarbaru. Apabila dilihat dari t-hitung variabel bebas maka variabel kepemimpinan kepala sekolah $\left(\mathrm{X}_{1}\right)$ yang memiliki t-hitung 4.104 lebih besar dari t-tabel sebesar 2.000 dengan probabilitas 0,000 dapat dikatakan bahwa hipotesis yang diajukan dalam penelitian ini, yang menyatakan diduga bahwa faktor 
kepemimpinan kepala sekolah melalui memberikan informasi dengan akurat, menyertakan partisipasi guru dalam mengambil, keputusan mengikutsertakan komite sekolah dalam mengambil keputusan, menunjukan kewibawaan dalam melaksanakan tugas, memberikan pengarahan sebelum menyerahkan tugas kepada guru, mendukung peningkatan pendidikan yang dimiliki guru, mendukung kompetensi yang dimiliki guru, memberi peluang kepada guru untuk mengikuti diklat yang relavan, menggunakan komunikasi secara formal dengan orang tua siswa, memberikan dorongan kepada guru untuk melakukan pekerjaan dengan cara-cara baru yang lebih inovatif mempunyai pengaruh terhadap kinerja guru SMP Negeri 4 Banjarbaru terbukti.

Koefisien regresi faktor kepemimpinan kepala sekolah (X1) adalah sebesar 0.222, hal ini menunjukkan hubungan positif atau searah dengan kinerja guru (Y) SMP Negeri 4 Banjarbaru artinya apabila faktor kepemimpinan kepala sekolah $\left(\mathrm{X}_{1}\right)$ dilaksanakan sesuai kebutuhan maka dapat berjalan lancar, maka kinerja guru pada SMP Negeri 4 Banjarbaru akan meningkat dengan baik.

Dengan demikian dapat disimpulkan bahwa kepemimpinan kepala sekolah yang diberikan pada SMP Negeri 4 Banjarbaru memberikan kontribusi pengaruh terhadap kinerja guru Oleh karenanya apabila kepemimpinan kepala sekolah yang telah diberikan secara langsung maupun tidak langsung tersebut dijalankan dengan baik dan benar dapat dijadikan sebagai dasar untuk meningkatkan semangat kerja.

b. Pengaruh Kompetensi profesional Terhadap Kinerja guru

Berdasarkan Tabel 5.34 dapat dijelaskan bahwa variabel kompetensi profesional yang mempunyai nila $t$-hitung $>$ nilai $t$-Tabel berarti bahwa variabel tersebut pada taraf nyata (5\%) mempunyai pengaruh yang bermakna terhadap kinerja guru pada SMP Negeri 4 Banjarbaru. Nilai t-hitung untuk perencanan $3.162>$ t-Tabel sebesar 2.000 dengan probabilitas sebesar 0,04 lebih tinggi dari $\alpha=0,05$ atau lebih besar dari taraf nyata $5 \%$. Hal ini menunjukkan bahwa pengaruh kompetensi profesional $\left(\mathrm{X}_{2}\right)$ yang terdiri mengatur kelas untuk memberikan kesempatan belajar yang sama pada semua peserta didik dengan kelainan fisik dan kemampuan belajar yang berbeda, mencoba mengetahui penyebab penyimpangan perilaku peserta didik untuk mencegah agar perilaku tersebut tidak merugikan peserta didik lainnya, memberi kesempatan kepada peserta didik untuk menguasai materi pembelajaran sesuai kemampuan belajarnya melalui pengaturan proses pembelajaran dan aktivitas yang bervariasi, selalu memastikan tingkat pemahaman peserta didik terhadap materi pembelajaran tertentu dan menyesuaikan aktivitas pembelajaran berikutnya berdasarkan tingkat pemahaman tersebut, dapat menjelaskan alasan pelaksanaan kegiatan/aktivitas yang dilakukannya, baik yang sesuai maupun yang berbeda dengan rencana, terkait keberhasilan pembelajaran, menyusun silabus yang sesuai dengan kurikulum, merancang rencana pembelajaran yang sesuai dengan silabus untuk membahas materi ajar tertentu agar peserta didik dapat mencapai kompetensi dasar yang ditetapkan, mengikuti urutan materi pembelajaran dengan memperhatikan tujuan pembelajaran, melaksanakan aktivitas pembelajaran yang bertujuan untuk membantu proses belajar peserta didik, bukan untuk menguji sehingga membuat peserta didik merasa tertekan, mengkomunikasikan informasi baru (misalnya materi tambahan) sesuai dengan usia dan tingkat kemampuan belajar peserta didik terhadap kinerja guru pada SMP Negeri 4 Banjarbaru adalah signifikan.

Koefisien regresi kompetensi profesional $\left(\mathrm{X}_{2}\right)$ adalah sebesar 0.167 , hal ini menunjukkan hubungan positif atau searah dengan kinerja guru (Y) SMP Negeri 4 Banjarbaru. Artinya apabila faktor kompetensi profesional sesuai porsi masing-masing, maka kinerja guru (Y) SMP Negeri 4 Banjarbaru akan meningkat dengan baik. Dengan 
demikian adanya kompetensi profesional belum dapat memberikan kinerja yang baik bagi guru.

\section{Pengaruh Secara Simultan}

Selanjutnya dari hasil penghitungan model persamaan regresi linier berganda di atas menunjukkan antara kepemimpinan kepala sekolah $\left(\mathrm{X}_{1}\right)$ dan kompetensi profesional $\left(\mathrm{X}_{2}\right)$ secara bersama-sama (serentak) mempengaruhi kinerja (Y) pada guru pada SMP Negeri 4 Banjarbaru sebagai variabel bebas mempunyai pengaruh positif. Pengaruh tersebut menunjukkan bahwa kedua faktor sebagai variabel bebas berubah searah dengan perubahan kinerja sebagai variabel tidak bebas.

Kemudian untuk mengetahui kepemimpinan kepala sekolah $\left(\mathrm{X}_{1}\right)$ dan kompetensi profesional $\left(\mathrm{X}_{2}\right)$, dan disiplin kerja $\left(\mathrm{X}_{3}\right)$ berpengaruh terhadap variabel (Y) yakni kinerja pada Guru pada SMP Negeri 4 Banjarbaru dapat dilakukan Uji F.

Dengan Uji Serentak (Uji F) digunakan untuk membuktikan atau menguji kebenaran hipotesis pertama yang akan diajukan dalam penelitian iniyang terdiri kepemimpinan kepala sekolah $\left(\mathrm{X}_{1}\right)$ dan kompetensi profesional $\left(\mathrm{X}_{2}\right)$ secara serentak berpengaruh terhadap kinerja Guru pada SMP Negeri 6 Palangka Raya.Adapun hasil perhitungan dengan menggunakan microstat diperoleh hasil uji serentak (Uji F), seperti terlihat pada Tabel sebagai berikut.

Tabel 4. Hasil Uji F

\begin{tabular}{ccccc}
\hline F Hitung & $\mathrm{F}_{\text {Tabel }}$ & $\mathrm{R}$ & $\mathrm{R}$ square & Sig $\alpha=0,05$ \\
\hline 14.407 & 3.74 & .719 & .516 & 0,000 \\
\hline
\end{tabular}

Berdasarkan Uji serentak (Uji F) ini dilakukan dengan membandingkan $\mathrm{F}_{\text {hitung }}$ dengan $\mathrm{F}$ Tabel pada taraf nyata $\alpha=0,05$. Dari hasil perhitungan data pada Tabel 5.36 dapat dilihat bahwa nilai $\mathrm{F}$ hitung 14.407> $\mathrm{F}$ Tabel 3.74 dengan probabilitas sebesar 0,000, hal ini berarti bahwa pada taraf nyata $\alpha=0,05$ dapat dikatakan kepemimpinan kepala sekolah $\left(\mathrm{X}_{1}\right)$ dan kompetensi profesional $\left(\mathrm{X}_{2}\right)$ mempunyai pengaruh yang berarti terhadap kinerja Guru pada SMP Negeri 4 Banjarbaru atau dengan perkataan lain bahwa dengan taraf nyata $5 \%$, hipotesis pertama diterima (terbukti).

Adapun besarnya kontribusi seluruh variabel kehidupan kerja (X) terdiri kepemimpinan kepala sekolah $\left(\mathrm{X}_{1}\right)$ dan kompetensi profesional $\left(\mathrm{X}_{2}\right)$, ditunjukkan dengan angka $\mathrm{R}^{2}$ sebesar 0, 516. Angka ini mengandung arti bahwa seluruh variabel bebas (kepemimpinan kepala sekolah $\left(\mathrm{X}_{1}\right)$ dan kompetensi profesional $\left(\mathrm{X}_{2}\right)$ yang digunakan dalam persamaan regresi ini, secara serentak (bersama-sama) mampu memberikan kontribusi terhadap kinerja Guru pada SMP Negeri 4 Banjarbaru sebesar 0.516 atau dengan kata lain secara serentak (bersama-sama) berpengaruh terhadap kinerja sebesar 51,6 \%, sedangkan sisanya sebesar 48,4\% dipengaruhi oleh variabel lain diluar variabel yang ada.

Sedangkan Angka Multiple $\mathrm{R}$ adalah 0,719 artinya bahwa kontribusi faktor kepemimpinan kepala sekolah $\left(\mathrm{X}_{1}\right)$ dan kompetensi profesional $\left(\mathrm{X}_{2}\right)$ terhadap kinerja Guru pada SMP Negeri 4 Banjarbaru. Koefisien $\mathrm{R}^{2}$ mengukur proporsi atau prosentasi total variasi dalam kinerja sebagai variabel $\mathrm{Y}$ yang dijelaskan oleh model regresi pada variabel $\mathrm{X}$ yakni kepemimpinan kepala sekolah dan kompetensi profesional. Terlihat Koefisien determinasi bergerak dari 0 sampai 1, karena memiliki angka/nilai 0,884 berarti semakin mendekati 1, dalam artian faktor kepemimpinan kepala sekolah $\left(\mathrm{X}_{1}\right)$ dan kompetensi profesional $\left(\mathrm{X}_{2}\right)$ memberikan kontribusi yang signifikan terhadap kinerja. 


\section{Pengaruh Secara Dominan}

Untuk melihat seberapa besar kontribusi pengaruh parsial dari variabel-variabel bebas terhadap variabel bergantung, perlu dihitung koefisien korelasi parsial dari masing-masing variabel bebas tersebut. Koefisien determinasi parsial menunjukkan kontribusi pengaruh suatu variabel bebas terhadap variabel tergantung dengan membuat variabel-variabel bebas lainnya konstan atau tetap. Untuk mendapatkan koefisien determinasi parsial tersebut adalah dengan cara mengkuadratkan koefisien parsial yang diperoleh.

Data yang diperoleh menunjukkan bahwa pengaruh parsial terbesar terhadap variabel kinerja Guru pada SMP Negeri 4 Banjarbaru adalah kepemimpinan kepala sekolah yaitu sebesar $4.104^{2}$ atau menjadi 17.13 persen. Hal ini sesuai dengan nilai koefisien regresi variabel bahwa kepemimpinan kepala sekolah yang memiliki nilai terbesar dibandingkan variabel lainnya pada taraf nyata $\alpha=0,05$ mempunyai pengaruh secara dominan terhadap variabel kinerja Guru pada SMP Negeri 4 Banjarbaru atau dengan perkataan lain bahwa dengan taraf nyata $5 \%$, hipotesis yang menyatakan kepemimpinan memiliki pengaruh yang dominan terhadap kinerja Guru pada SMP Negeri 4 Banjarbaru diterima (terbukti).

Dalam merancang Program Pengembangan Guru SMP Negeri 4 Banjarbaru ke dalam program kerja pembinaan terhadap kepemimpinan kepala sekolah yang tercantum ke dalam program kerja jangka pendek dan jangka panjang, dengan maksud agar program kerja dapat dilaksanakan tahap demi tahap dengan tidak mengabaikan daya guna dan hasil gunanya. Di samping itu juga memberikan penugasan dan kelonggaran kepada Guru SMP Negeri 4 Banjarbaru untuk menempuh pendidikan di lembaga-lembaga yang berkompeten dengan pendidikan formal maupun pendidikan luar sekolah yang .

Pengembangan Guru SMP Negeri 4 Banjarbaru dibutuhkan untuk menyesuaikan diri dengan kemajuan dan teknologi, seperti pemahaman kemampuan dan keterampilan dibidang komputer dan komunikasi yang semuanya memerlukan alat yang canggih, disamping itu pengembangan dapat meningkatkan kinerja Guru SMP Negeri 4 Banjarbaru ke depan.

Pada prinsipnya. Tugas Guru SMP Negeri 4 Banjarbaru melayani kepentingan siswa sesuai dengan bidang tugasnya masing-masing sejalan dengan dinamika kehidupan bidang pendidikan dan pelaksanaan proses belajar mengajar, maka cakupan tugas SMP Negeri 4 Banjarbaru tampak semakin kompleks dan krusial, sehingga membutuhkan guru yang berkualitas, professional dan mempunyai mental guru yang handal dalam rangka pelaksanaan tugas membangun generasi masyarakat yang berkualitas.

Pengembangan guru dalam rangka meningkatkan guru SMP Negeri 4 Banjarbaru melalui tiga jalur yaitu : Jalur Pendidikan, jalur pengembangan maupun pembinaan. Salah satu upaya pembentukan dan peningkatan profesionalitas kerja SMP Negeri 4 Banjarbaru adalah dilakukan melalui pengembangan yakni kepemimpinan kepala sekolah

Keberhasilan dalam menjelankan tugas bagi SMP Negeri 4 Banjarbaru sangat berhubungan erat dengan pengetahuan pekerjaan yang tersedia dan dihadapinya dalam suatu organisasi. Pengetahuan pekerjaan ini akan berkaitan dengan penguasaan teknik tugas, pengetahuan pekerjaan relevan akan menentukan kualitas tugas yang dilaksanakan sehingga pengetahuan pekerjaan berkaitan dengan latar belakang pendidikan sebelum seseorang guru SMP Negeri 4 Banjarbaru memikul tugas atau tanggung jawab dalam melaksanakan pendidikan.

Pada dasarnya tingkat pendidikan merupakan hal yang sangat penting dalam menunjang dan memudahkan seseorang untuk menyelesaikan tugas yang dibebankan kepadanya. Pendidikan harus dimiliki tentunya pendidikan dan pengetahuan yang sesuai dengan bidang tugas dan pekerjaan yang nantinya akan memudahkan dalam penyelesaian berbagai permasalahan terutama yang berkenaan dengan tugas dalam proses belajar mengajar. Dalam 
mengembangkan dan meningkatkan kinerja Guru SMP Negeri 4 Banjarbaru harus pula dapat meningkatkan semangat kerja tentunya dengan memiliki tingkat pendidikan dan kemampuan seluruh komponen organisasi dan mendorong sikap keterbukaan manajemen. Dari penjelasan terdahulu, bahwa tingkat pendidikan Guru SMP Negeri 4 Banjarbaru belum cukup baik dan perlu ditingkatkan, hal ini apabila dilihat dari komposisi tingkat pendidikan yang dimiliki guru SMP Negeri 4 Banjarbaru.. Dengan pendidikan akan lebih berorientasi pada peningkatan produktivitas kerja pada masa kini dan masa akan datang. Begitu juga halnya dalam mengikuti kepemimpinan kepala sekolah akan memberikan nilai bagi diri sendiri dalam meningkatkan kemampuan dan pengetahuan yang dapat diberikan kepada sesama rekan kerja dalam mencapai tujuan organisasi.

Dalam penyelenggaraan pendidikan, pelaksanaan pembangunan dalam konteks kinerja guru, diperlukan kesiapan dan kualitas guru yang memadai. Upaya yang perlu ditempuh segera untuk mengalokasikan dana yang cukup besar. Dalam program jangka panjang tujuan pengembangan agar menciptakan sumber daya guru yang berkualitas. Guru SMP Negeri 4 Banjarbaru sebagai abdi negara dan abdi masyarakat dalam jangka pendek pengembangan Guru harus dapat meningkatkan kinerja guru.

Dengan adanya perubahan zaman yang sangat pesat ditandai adanya kemajuan ilmu pengetahuan dan teknologi sehingga untuk mengikuti perubahan tersebut diperlukan pengembangan sumber daya.

Pengembangan Guru SMP Negeri 4 Banjarbaru dibutuhkan untuk menyesuaikan diri dengan kemajuan dan teknologi, seperti pemahaman kemampuan dan keterampilan dibidang komputer dan komunikasi yang semuanya memerlukan alat yang canggih, disamping itu pengembangan dapat meningkatkan kinerja Guru SMP Negeri 4 Banjarbaru ke depan.

\section{Kesimpulan}

Berdasarkan pada hasil penelitian ini, dapat dibuat serangkaian kesimpulan yang disajikan sebagai berikut:

1. Terdapat pengaruh signifikan secara parsial antara kepemimpinan kepala sekolah dan kompetensi profesuonal terhadap kinerja guru SMP Negeri 4 Banjarbaru.

2. Terdapat pengaruh signifikan secara simultan antara kepemimpinan kepala sekolah dan kompetensi profesuonal terhadap kinerja guru SMP Negeri 4 Banjarbaru.

3. Kepemimpinan kepala sekolah mempunyai pengaruh dominan terhadap kinerja dapat dibuktikan karena dari keseluruhan faktor-faktor yang diteliti ternyata dari hasil pembuktikan hipotesis dapat dibuktikan dengan angka paling besar.

Dengan mempertimbangkan hasil dari penelitian ini, disarankan untuk meningkatkan kinerja perlu adanya kompetensi profesional kerja agar dapat meningkatkan kemampuan kerja yang ditentukan oleh pemenuhan kebutuhan. Dalam Pelaksanaan kegiatan perlunya adanya kesempatan yang diberikan pimpinan terhadap sumber daya manusia (guru) yang diberdayakannya untuk memperoleh hal tersebut perlu adanya ketegasan terhadap peraturan yang digunakan sebagai upaya peningkatan SDM secara menyeluruh.

\section{DAFTAR PUSTAKA}

Ali, Muhammad 2006. Guru Dalam Proses Belajar Mengajar. Bandung : Sinar. Baru Algensindo.

Anwar, Yasin. 2003. Standar Kemampuan Profesional Guru SD. IKIP Malang, Ariknto, Suharsimi. 2006. Prosedur Penelitian Suatu Pendekatan Praktik. Jakarta: Rineka Cipta.

Suharsimi. 2009. Dasar-Dasar Evaluasi Pendidikan Edisi Revisi. Jakarta: Bumi Aksara. 
As'ad, moh .2006. Seri Ilmu SDM : Psikologi Industri. Edisi Keempat. Yogyakarta : Liberty. Atmodiwirio, Soebagio dan Totosiswanto, Soeranto. 2014. Kepemimpinan Profesionalisme tenaga Kependidikan. Bandung: Pustaka Setia

Attwood, M, \& Dimmock, S. 2009. Manajemen Personalia (Kusnedi, penerjemah). Bandung: Penerbit ITB.

Danim, Sudarman 2010. Motivasi Kepemimpinan dan Efektivitas Kelompok. Jakarta : Penerbit Rineka Cipta.

Danim, Sudarwan \& Suparno. 2009. Manajemen Kepemimpinan Transformasional Kepala Sekolah. Jakarta : PT. Rineka Cipta

Daryanto. 2008. Evaluasi Pendidikan. Jakarta: PT. Rineka Cipta

Depdiknas. 2016. Tentang Kurikulum Tingkat Satuan Pendidikan (KTSP). Jakarta :Depdiknas.

Dessler, G. (2007). Human Resource Management (7th Ed.). Upper Saddle River, NJ: Association

Djamarah,Syaiful Bahri.2015. Strategi Belajar Mengajar. Jakarta:Rineka Cipta.

Fachruddin Saudagar, 2009. Pengembangan Profesionalisme Guru,. Jakarta: Gaung Persada.

Fernandez, H.J.K. 2004. Evaluation of educational programmes. Jakarta: BP3K-September.

Fikri, Arief. 2013. Profesional Guru. www.tarakankota.go.id/in/Rubrik_Kita.php?op =tarakan $\& \operatorname{mid}=231$

Gibson, James L, Ivancevich, John M. Donnely JR, James H. 2009. Organisasi Perilaku, Struktur, Proses. Edisi Kedelapan. Jakarta : Bina Rupa Aksara..

Gumelar, Awan dan Tjep Dahyat. (2012). Kapita Selekta MBS Pengelolaan. Pendidikan Yang Profesional Berwawasan Masa Depan, Relevan, dan Lebih Bermutu. Bandung : Gatra Kara Prima

Gunawan \& Marzuki, (2016). Statistik Terapan Untuk Penelitian Ilmu. Sosial, Yogyakarta : Gajah Mada University Press.

Hamalik,Oemar. 2015. Kurikulum dan Pembelajaran. Jakarta: Bumi Aksara

Haryati, M. 2007. Model Dan Teknis Penilaian Pada Satuan Tingkat Pendidikan. Jakrta : Gaung Perkasa Press

Herawan, Denny. 2009. Peningkatan Kompetensi guru dapat meningkatkan pembinaan peserta didik. Makalah Pribasi Blog.www/Denny/com.

Joni, Raka. T. 2014. Pengukuran dan Penilaian Pendidikan. Malang: Bang Evaluasi IKIP Malang

Keputusan Menteri Pendidikan Nasional nomor 0296/U/1996 tentang Penugasan Guru sebagai Kepala Sekolah.

Kunandar.2010. Kepala Sekolah Profesional.Jakarta: PT. Rajagrafindo Persada

Kusmintardjo .2008. Pengelolaan Layanan Khusus di Sekolah (Jilid II). Malang: IKIP Malang.

Majid, Abdul 2007. Perencanaan Pembelajaran. (Mengembangkan Standar. Kompetensi guru). Bandung : Remaja Rosdakarya

Mangkunegara Anwar Prabu. 2006. Evaluasi Kinerja SDM. Jakarta : Refika Adhitama

Masnur, Muslich 2010. KTSP Pembelajaran Berbasis Kompetensi dan Kontekstual. Jakarta :BumiAksara.

Mulyasa. 2014. Menjadi Guru Profesional. PT. Remaja. Rosdakarya. Bandung.

Mulyasa, 2007. Manajemen Berbasis Sekolah. Bandung: Remaja Rosdakarya . 